\title{
Iron limitation enhance organic matter sulfurization within the limestones of the Ediacaran Dengying Formation
}

FUMIHIRO MATSU'URA ${ }^{1 *}$ RYOICHI NAKADA ${ }^{2}$ YUICHIRO UENO $^{3,4,5}$ YUSUKE SAWAKI $^{6}$ MASAFUMI SAITOH $^{7}$ IORI KAJITANI $^{1}$, TOMOHIRO USUI ${ }^{1,4}$

${ }^{1}$ ISAS, JAXA, Kanagawa, Japan

(*correspondence: matsuura.fumihiro@jaxa.jp)

${ }^{2}$ KOCHI JAMSTEC, Kochi, Japan

${ }^{3}$ Dept. EPS, Tokyo Tech., Tokyo, JAPAN

${ }^{4}$ ELSI, Tokyo Tech., Tokyo, JAPAN

${ }^{5}$ JAMSTEC, Yokosuka Kanagawa, JAPAN

${ }^{6}$ EA, Komaba, The Univ. of Tokyo, Tokyo, JAPAN

${ }^{7}$ ISTE, Université de Lausanne, Lausanne, Switzerland

The difference of sulfur isotopic composition of sedimentary sulfate and sulfide has been used to reconstruct palaeo-oceanic sulfate concentration. For the palaeo-marine study, pyrite $\delta^{34} \mathrm{~S}$ has been utilized without considering pyrite concentration that may control sulfur cycle within the sediments.The limestones in the Shibantan Member, the Ediacaran Dengying Formation (Fm.), South China, have minor amount of carbonate associated iron $\left(\mathrm{Fe}_{\text {carb }}\right)$ concomitant with low pyrite concentration compared to the limestones and dolostones in the preceding Ediacaran Doushantuo Fm. Given the adequate total organic carbon (TOC) content in the Shibantan limestones, pyrite content is controlled by oceanic sulfate concentration or reactive iron supply into the sediments. Here we investigated species and concentration of sulfur in the limestone matrix of the Shibantan Member of Dengying Formation and the Member 3 of Doushantuo Fm by $\mu$-X-ray fluorescence (XRF) mapping and S K-edge X-ray absorption near edge structure (XANES) analyses. The XANES spectra of Dengying limestones show the existence of organic sulfur and carbonate associated sulfate (CAS). The XRF results of two Dengying limestones suggest that the average organic sulfur contents are 374 and $436 \mathrm{ppm}$. In contrast, the XANES spectra in the Doushuntuo limestone indicate that the $\mathrm{S}$ occurs dominantly as CAS. The systematic difference in XANES spectra between the Doushantuo and Dengying formations suggests that the sedimentary sulfur cycle, controlled by reactive iron supply, was different during the deposition of the Doushantuo and Dengying formations. In particular, iron limitation during the deposition of Dengying Fm. may have enhanced sulfurization of organic matter and alterd pyrite $\delta^{34} \mathrm{~S}$ value. 